\title{
Tryptic digestion of peptides corresponding to modified fragments of human growth hormone-releasing hormone ${ }^{\star}$
}

\author{
Ewa Witkowska ${ }^{\bowtie}$, Alicja Orłowska and Jan Izdebski \\ Laboratory of Peptides, Faculty of Chemistry, Warsaw University, L. Pasteura 1, \\ 02-093 Warszawa, Poland
}

Received: 31 October, 2003; revised: 04 February, 2004; accepted: 08 February, 2004

Key words: hGH-RH fragments, tryptic digestion, P2 position

\begin{abstract}
The objective of this study was to examine the degradation of short peptides corresponding to modified fragments of human growth hormone-releasing hormone by trypsin. Six analogues of pentapeptide 9-13 of human growth hormone-releasing hormone containing homoarginine, ornithine, glutamic acid, glycine, leucine or phenylalanine residue in position 11, two analogues of hexapeptide 8-13 of human growth hormone-releasing hormone and two analogues of heptapeptide 7-13 of human growth hormone-releasing hormone containing homoarginine or glycine residue in position 11 were obtained. The peptides were subjected to digestion by trypsin and the course of reaction was monitored using HPLC. It was found that the rate of hydrolysis of the $\mathrm{Lys}^{12}$-Val ${ }^{13}$ peptide bond depends on the amino-acid residue preceding Lys ${ }^{12}$. The extension of the peptide chain towards the $\mathrm{N}$-terminus by introduction of consecutive amino-acid residues corresponding to the human growth hormone-releasing hormone sequence accelerates the hydrolysis process. These results may be of assistance in designing new analogues of human growth hormone-releasing hormone, more resistant to the activity of proteolytic enzymes.
\end{abstract}

The hypothalamic peptide growth hormonereleasing hormone (GH-RH) is the major physiological stimulus of growth hormone
(GH) secretion and an important regulator of GH messenger RNA synthesis in the anterior pituitary. Clinical studies on hGH-RH have

\footnotetext{
${ }^{\star}$ Presented at the 17th Polish Peptide Symposium, August 31st-September 4th, 2003, Łódź, Poland.

${ }^{凶}$ Corresponding author: Ewa Witkowska, Laboratory of Peptides, Department of Chemistry, Warsaw University, L. Pasteura 1, 02-093 Warsaw, Poland; fax: (48 22) 822 5996; e-mail: ewawit@chem.uw.edu.pl

Abbreviations: Boc, $t$-butoxycarbonyl; Bzl, benzyl; Dat, desaminotyrosine; DCM, dichloromethane; DIC, diisopropylcarbodiimide; DIEA, diisopropylethylamine; Fmoc, 9-fluorenylmethoxycarbonyl; Har, homoarginine; hGH-RH, human growth hormone-releasing hormone; HOBt, 1-hydroxybenzotriazole; MBHA, 4-methylbenzhydrylamine; Nle, norleucine; Orn, ornithine; SPPS, solid phase peptide synthesis; TFA, trifluoroacetic acid; $\mathrm{Z}$, benzyloxycarbonyl; $\mathrm{Z}(2 \mathrm{Br})$, 2-bromobenzyloxycarbonyl; $\mathrm{Z}(2 \mathrm{Cl})$, 2-chlorobenzyloxycarbonyl.
} 
demonstrated that hGH-RH and related analogues may prove to be the most physiological replacement therapy for many GH-deficient patients (Gelato et al., 1985; Thorner et al., 1985; Ross et al., 1987). Although native hGH-RH has a length of 44 residues, synthetic hGH-RH(1-29)- $\mathrm{NH}_{2}$ of the structure Tyr-Ala-Asp-Ala-Ile-Phe-Thr-Asn-Ser-Tyr ${ }^{10}$-ArgLys-Val-Leu-Gly-Gln-Leu-Ser-Ala-Arg ${ }^{20}$-Lys-LeuLeu-Gln-Asp-Ile-Met-Ser-Arg ${ }^{29}-\mathrm{NH}_{2}$ displays full biological activity and is the shortest fragment endowed with this property (Wehrenberg \& Ling, 1983).

Although the usefulness of hGH-RH and its shorter analogue for medical applications has been demonstrated, there is still a great demand for more stable analogues, which would allow doses and frequency of administration to be reduced.

It has been reported that hGH-RH(1-29)$-\mathrm{NH}_{2}$ is rapidly metabolized in plasma, as a result of $\mathrm{Ala}^{2}-\mathrm{Asp}^{3}$ peptide bond cleavage by dipeptidylpeptidase IV leading to the inactive GH-RH(3-29)-NH $\mathrm{NH}_{2}$ (Frohman et al., 1986). The other metabolites observed were characteristic of trypsin-like cleavages between Arg $^{11}$-Lys ${ }^{12}$ and Lys ${ }^{12}$-Val $^{13}$ (Frohman et al., 1989). Numerous analogues of hGH-RH have been synthesized and tested to obtain compounds with increased metabolic stability and potency (Lance et al., 1984; Kubiak et al., 1993; Campbell et al., 1994; Izdebski et al., 1995). Recently, we demonstrated that the hGH-RH(1-29)- $\mathrm{NH}_{2}$ analogue was cleaved by trypsin at all basic amino-acid residues, including the C-terminal amide bond, but an analogous sequence, that differed in that it contained Orn instead of Lys, was cleaved only at Arg residues (Witkowska et al., 2001). Thus, in order to further increase the metabolic stability, modifications at positions occupied by Arg residues were needed. Therefore, we synthesized four novel analogues of hGH-RH(1-29)- $\mathrm{NH}_{2}$ containing homoarginine (Har) or D-Arg residues instead of Arg and Lys: (1) [Dat ${ }^{1}, \mathrm{Ala}^{15}, \mathrm{Nle}^{27}, \mathrm{Asp}^{28}, \mathrm{D}-\mathrm{Arg}^{29}{ }^{2}$ hGH-RH(1-29)-NH ${ }_{2}$, (2) [Dat ${ }^{1}$, Har $^{12,21}$, Ala $^{15}$,
$\mathrm{Nle}^{27}, \mathrm{Asp}^{28}{ }^{2} \mathrm{D}-\mathrm{Arg}^{29}$ ]hGH-RH(1-29)-NH ${ }_{2}$, (3) $\left[\mathrm{Dat}^{1}{ }^{1}, \mathrm{Har}^{20,29}, \mathrm{Ala}^{15}, \mathrm{Nle}^{27}, \mathrm{Asp}^{28}{ }^{2}\right.$ hGH-RH(1-29)- $\mathrm{NH}_{2}$, (4) [Dat ${ }^{1}, \mathrm{Har}^{11,20,29}, \mathrm{Ala}^{15}$, $\mathrm{Nle}^{27}, \mathrm{Asp}^{28}$ ]hGH-RH(1-29)-NH $\mathrm{NH}_{2}$. We decided to use an isolated enzyme - trypsin as a representative of trypsin-like enzymes. It was observed that after digestion for a prolonged period of time all peptide bonds formed by the carboxyl groups of Lys and Arg undergo complete cleavage, but those at Har remained intact. In addition, the amide bond formed with Har or D-Arg at position 29 was stable. Analysis of products obtained after 15 min digestion allowed intermediate peptides to be observed. Comparison of fragments formed as a result of digestion of analogues (1), (3) and (4) indicates that the hydrolysis of peptide bonds between $\mathrm{Lys}^{12}-\mathrm{Val}^{13}$ and $\mathrm{Lys}^{21}-\mathrm{Leu}^{22}$ is slower when homoarginine instead of arginine precedes the lysine residue in the peptide chain (Izdebski et al., 2002).

In this work we present the results of our studies on the influence of amino-acid residues adjacent to $\mathrm{Lys}^{12}$ (i.e. the P2 position) on the hydrolysis rate of the $\mathrm{Lys}^{12}-\mathrm{Val}^{13}$ bond by trypsin in modified fragments of hGH-RH. The analogues of the pentapeptide fragment hGH-RH(9-13)- $\mathrm{NH}_{2}$ with Arg in position 11 replaced by Har, Orn, Glu, Gly, Leu and Phe were synthesized and subjected to digestion by trypsin. In order to compare the effect of the extension of the peptide chain on the rate of hydrolysis, two hexapeptides hGH-RH(8-13)- $\mathrm{NH}_{2}$ and two heptapeptides hGH$\mathrm{RH}(7-13)-\mathrm{NH}_{2}$ containing Har or Gly residue in position 11 instead of Arg have also been synthesized and subjected to tryptic hydrolysis.

\section{MATERIALS AND METHODS}

Peptide synthesis. Peptides were synthesized by SPPS using the Boc strategy and carbodiimide (DIC) as the coupling reagent. The side-chain functions of the Boc-amino acids were protected as follows: $\mathrm{Glu}(\mathrm{Bzl})$, 
Lys(Fmoc), Lys[Z(2Cl)], Orn(Z), Ser(Bzl), Thr(Bzl), Tyr[Z(2Br)]. Peptides were synthesized on MBHA resin $(0.45 \mathrm{mmole} / \mathrm{g}$, Peptides International). TFA (55\%)/DCM was used in all deprotection steps. Neutralizations were carried out with 5\% DIEA/DCM. Boc-Asn was introduced using the carbodiimide DIC/HOBt method. Every coupling step was monitored with the Kaiser color test. When needed, acylation was repeated. Introduction of the guanidine group (peptides 1, $\mathbf{7}$, 9) was performed using $N, N^{\prime}$-bis(tert-butoxycarbonyl)-S-methylisothiourea following the removal of the Fmoc group from the amino function of the side chain of Lys (Izdebski et al., 2002). This protection was removed by treatment with piperidine after the peptide chain was assembled. Then the peptide-resin was guanidinylated. This process was monitored using the Kaiser color test, and was judged finished when free amino groups were not detected.

Following the removal of the Boc group, samples of peptide-resins were treated with $\mathrm{HF}\left(0^{\circ} \mathrm{C}, 1 \mathrm{~h}\right)$ in the presence of anisol. The crude peptides were purified using a Knauer HPLC system with Vertex column Nucleosil $300 \mathrm{C}_{18}(8 \times 250 \mathrm{~mm}, 5 \mu \mathrm{m})$; solvent system: $\mathrm{A}, 0.05 \%$ TFA in water, $\mathrm{B}, 60 \% \mathrm{MeCN}$ in water. Fractions were eluted from the column with a linear gradient: peptide $\mathbf{1}, \mathbf{2}, \mathbf{3}, \mathbf{4}, \mathbf{7}, \mathbf{8}$, 9 and 10, 2-8\% B in 60 min; peptide 5, $8-15 \%$ B in 50 min; peptide $6,10-20 \%$ B in 55 $\mathrm{min}$; flow rate $2 \mathrm{ml} / \mathrm{min}$; detection at $220 \mathrm{~nm}$. Fractions were analyzed with the same system equipped with a Eurospher $100 \mathrm{C}_{18}(4.6 \times$ $250 \mathrm{~mm}, 5 \mu \mathrm{m})$ column using gradient: peptides $\mathbf{1}, \mathbf{2}, \mathbf{3}, \mathbf{4}, \mathbf{7}, \mathbf{8}, \mathbf{9}$ and $\mathbf{1 0}, 10-40 \% \mathrm{~B}$ in 20 min; peptides 5 and $\mathbf{6}, \mathbf{2 5 - 5 5 \% ~ B ~ i n ~} 20$ $\mathrm{min}$; flow rate $1 \mathrm{ml} / \mathrm{min}$; detection at $220 \mathrm{~nm}$. The structure of the peptides was confirmed by ESI-MS using a Mariner Biospectrometry Workstation PerSeptive Biosystem in the Laboratory of Spectroscopy at the Department of Chemistry, Warsaw University.

Tryptic hydrolysis of peptides. A sample of peptide (1 mg) was dissolved in ammo- nium acetate buffer (100 $\mu \mathrm{l}, 0.05 \mathrm{M}, \mathrm{pH}$ 8.5) and incubated at $37^{\circ} \mathrm{C}$ for $20 \mathrm{~min}$. Then a solution of trypsin ( $42 \mu \mathrm{l}, 0.02 \mathrm{mg} / \mathrm{ml}$; Serva, 36 $\mathrm{U} / \mathrm{mg}$ ) was added. The resulting solution was incubated at $37^{\circ} \mathrm{C}$ for $120 \mathrm{~min}$ and samples (24 $\mu \mathrm{l}$ ) were collected after 20, 45, 70, 95 and $120 \mathrm{~min}$. All samples were diluted with $25 \mu \mathrm{l}$ of $0.2 \%$ TFA. After centrifugation the samples were analyzed for remaining substrate by RP-HPLC using the Knauer system as above (peptide synthesis).

\section{RESULTS AND DISCUSSION}

Six analogues of pentapeptide hGH-RH(913) containing Har, Orn, Glu, Gly, Leu or Phe residue in position 11, two analogues of hexapeptide hGH-RH(8-13) amide fragment and two analogues of heptapeptide hGH$\mathrm{RH}(7-13)$ amide fragment containing Har or Gly residue in position 11 were synthesized according to solid phase protocols on the benzhydryl amino resin using DIC as a coupling reagent. Har residue was introduced by guanidinylation of the Lys side chain, exposed after peptide chain assembly, using $N, N^{\prime}$-bis(tert-butoxycarbonyl)-S-methylisothiourea.

The peptides were cleaved from the resin by treatment with liquid HF in the presence of anisole and purified by RP HPLC (Table 1).

The peptides were then subjected to digestion by trypsin. The course of digestion was monitored by RP-HPLC. The results presented in Table 2 show that after 120 min digestion less than $20 \%$ of the pentapeptide containing Orn residue was hydrolysed. In the case of pentapeptides containing Har, Glu or Gly the degree of hydrolysis was similar (30-38\%). Higher degradation was observed for pentapepides containing the Phe $(75 \%)$ or Leu residue (90\%).

Table 3 presents the results of digestion for the hexa- and heptapeptides. It can be seen that both the hexa- and heptapeptide containing the Har residue are hydrolysed to a larger 
degree than the corresponding peptides containing Gly in position 11. while the peptide containing Gly was hydrolysed in $78 \%$ after the same time.

Table 1. Synthesized modified fragments of hGH-RH and their relative molecular masses

\begin{tabular}{|c|c|c|c|}
\hline \multirow[t]{2}{*}{ Code } & \multirow[t]{2}{*}{ Peptide } & \multicolumn{2}{|c|}{ ESI MS $(\mathbf{M}+\mathbf{H})^{+}$} \\
\hline & & Calculated & Found \\
\hline 1 & Ser ${ }^{9}-$ Tyr-Har-Lys-Val ${ }^{13}-\mathrm{NH}_{2}$ & 664 & 665 \\
\hline 2 & Ser-Tyr-Orn-Lys-Val-NH 2 & 608 & 609 \\
\hline 3 & Ser-Tyr-Glu-Lys-Val-NH ${ }_{2}$ & 623 & 624 \\
\hline 4 & Ser-Tyr-Gly-Lys-Val- $\mathrm{NH}_{2}$ & 551 & 552 \\
\hline 5 & Ser-Tyr-Leu-Lys-Val-NH 2 & 607 & 608 \\
\hline 6 & Ser-Tyr-Phe-Lys-Val-NH 2 & 641 & 642 \\
\hline 7 & $\mathrm{Asn}^{8}$-Ser-Tyr-Har-Lys-Val ${ }^{13}-\mathrm{NH}_{2}$ & 778 & 779 \\
\hline 8 & Asn-Ser-Tyr-Gly-Lys-Val-NH 2 & 665 & 666 \\
\hline 9 & $\mathrm{Thr}^{7}$-Asn-Ser-Tyr-Har-Lys-Val ${ }^{13}-\mathrm{NH}_{2}$ & 879 & 880 \\
\hline 10 & Thr-Asn-Ser-Tyr-Gly-Lys-Val-NH 2 & 766 & 767 \\
\hline
\end{tabular}

A comparison of digestion results for the penta-, hexa- and heptapeptides containing Har or Gly residue clearly shows the influence of extension of the peptide chain on the rate of digestion. The presence of a longer peptide chain causes an increase of the rate of tryptic hydrolysis of the peptide bond. This in-

\section{CONCLUSIONS}

The aim of this study was to examine the rate of degradation by trypsin of short peptides corresponding to modified fragments of hGH-RH. Six analogues of pentapeptide hGH-RH(9-13) containing Har, Orn, Glu, Gly,

Table 2. Influence of amino-acid residue in position P2 on the rate of tryptic hydrolysis of analogues of pentapeptide hGH-RH(9-13)

\begin{tabular}{|c|c|c|c|c|c|}
\hline \multirow[b]{2}{*}{ Peptide } & \multicolumn{5}{|c|}{ Progress of hydrolysis (\%) } \\
\hline & $20 \mathrm{~min}$ & $45 \mathrm{~min}$ & $70 \mathrm{~min}$ & $95 \mathrm{~min}$ & $120 \mathrm{~min}$ \\
\hline Ser-Tyr-Orn-Lys-Val-NH 2 & 3 & 6 & 10 & 12 & 18 \\
\hline Ser-Tyr-Glu-Lys-Val- $\mathrm{NH}_{2}$ & 9 & 16 & 21.5 & 25 & 29.5 \\
\hline Ser-Tyr-Har-Lys-Val-NH 2 & 8 & 14.5 & 21 & 28.5 & 32.5 \\
\hline Ser-Tyr-Gly-Lys-Val-NH 2 & 8 & 17 & 25 & 31 & 38 \\
\hline Ser-Tyr-Phe-Lys-Val-NH 2 & 15 & 32 & 48 & 65.5 & 75 \\
\hline Ser-Tyr-Leu-Lys-Val-NH 2 & 20.5 & 42 & 62 & 78 & 90 \\
\hline
\end{tabular}

fluence is more pronounced for peptides containing the Har residue. The corresponding pentapeptides are hydrolysed to a similar degree, e.g. after $120 \mathrm{~min}$ the degree of digestion of pentapeptides with the Har or Gly residue is 33 and $38 \%$, respectively. However, the situation for heptapeptides is somewhat different. After 95 min digestion the peptide containing Har was completely degradated,
Leu or Phe residue in position 11, two analogues of hexapeptide hGH-RH(8-13) and two analogues of heptapeptide hGH-RH(7-13) containing Har or Gly residue in position 11 were obtained. The peptides were subjected to digestion by trypsin and the course of reaction was monitored using HPLC.

The presented results of tryptic digestion of the analogues of hGH-RH fragments indicate 
Table 3. The effect of peptide chain extension on the rate of tryptic hydrolysis of hGH-RH(7-13) and hGH-RH(8-13) analogues

\begin{tabular}{ccccccc}
\hline & \multicolumn{5}{c}{ Progress of hydrolysis (\%) } \\
& $20 \mathrm{~min}$ & $45 \mathrm{~min}$ & $70 \mathrm{~min}$ & $95 \mathrm{~min}$ & $120 \mathrm{~min}$ \\
\hline Asn-Ser-Tyr-Gly-Lys-Val-NH & & 14 & 28 & 37 & 52.5 & 59 \\
Thr-Asn-Ser-Tyr-Gly-Lys-Val-NH & & 32 & 47 & 63.5 & 78 & 85 \\
Asn-Ser-Tyr-Har-Lys-Val-NH & 13 & 31 & 51 & 69 & 84.5 \\
Thr-Asn-Ser-Tyr-Har-Lys-Val-NH & 53 & 70 & 92 & 100 & 100 \\
\hline
\end{tabular}

that the amino-acid residue preceding Lys in position 12 influences the hydrolysis rate of the peptide bond, while the extension of the peptide chain towards the N-terminus, by introduction of consecutive amino acids according to the hGH-RH sequence, always accelerates the hydrolysis process.

These results may be of assistance in designing new hGH-RH analogues more resistant to the activity of proteolytic enzymes.

The authors wish to thank Ms. Sylwia Kosewska and Ms. Ewa Nazaruk for experimental assistance.

\section{R E F E R E N C E S}

Campbell RM, Striker P, Bongers J, Liu W, Lambros T, Ahmad M, Felix AM, Heimer EP. (1994) Enhanced stability and potency of novel growth hormone-releasing factor (GRF) analogues derived from rodent and human GRF sequences. Peptides.; 15: 489-95.

Frohman LA, Downs TR, Williams TC, Heimer EP, Pan Y-CE, Felix AM. (1986) Rapid enzymatic degradation of growth hormone-releasing hormone by plasma in vitro and in vivo to biologically inactive product cleaved at the $\mathrm{NH}_{2}$ terminus. $J$ Clin Invest.; 78: 906-13.

Frohman LA, Downs TR, Heimer EP, Felix AM. (1989) Dipeptidylpeptidase IV and trypsin-like enzymatic degradation of human growth hormone-releasing hormone in plasma. J Clin Invest.; 83: 1533-40.
Gelato MC, Ross JL, Malozowski S, Pescovitz OH, Skeda M, Loriaux DL, Merriam GR. (1985) Effects of pulsatile administration of growth hormone (GH)-releasing hormone on short term linear growth in children with GH deficiency. J Clin Endocrinol Metab.; 61: 444-450.

Izdebski J, Pinski J, Horvath JE, Halmos G, Groot K, Schally AV. (1995) Synthesis and biological evaluation of superactive agonists of growth hormone-releasing hormone. Proc Natl Acad Sci USA.; 92: 4872-6.

Izdebski J, Witkowska E, Kunce D, Orłowska A, Baranowska B, Radzikowska M, Smoluch M. (2002) New potent hGH-RH analogues with increased resistance to enzymatic degradation. J Peptide Sci.; 8: 289-96.

Kubiak TM, Friedman AR, Martin RA, Ichhpureni AK, Alaniz GR, Clafin WH, Goodwin MC, Cleary DL, Kelly CR, Hilman RM, Downs TR, Frohman LA, Mosely WM. (1993) Position 2 and position $2 / \mathrm{Ala}^{15}{ }^{\text {-substi- }}$ tuted analogues of bovine growth hormonereleasing factor (bGRF) with enhanced metabolic stability and improved in vivo bioactivity. J Med Chem.; 36: 888-97.

Lance VA, Murphy WA, Sueiras-Diaz J, Coy D. (1984) Superactive analogs of growth hormone-releasing factor(1-29)-amide. Biochem Biophys Res Commun.; 119: 265-72.

Ross RJM, Tsagarakis S, Grossman A, Preece MA, Rodda C, Davis PSW, Rees LH, Savage MO. (1987) Treatment of growth-hormone deficiency with growth-hormone-releasing hormone. Lancet.; i: 5-8. 
Thorner MO, Reschke J, Chitwood J, Rogol AD, Furlanetto R, Rivier J, Vale W, Blizzard RM. (1985) Acceleration of growth in two children treated with human growth hormone-releasing factor. $N$ Engl $J$ Med.; 312: 4-9.

Wehrenberg WB, Ling N. (1983) In vivo biological potency of rat and human growth hormone-releasing factor and fragments of hu- man growth hormone-releasing factor. Biochem Biophys Res Commun.; 115: 525-30.

Witkowska E, Orłowska A, Sagan B, Smoluch M, Izdebski J. (2001) Tryptic hydrolysis of hGH-RH(1-29)- $\mathrm{NH}_{2}$ analogues containing Lys or Orn in position 12 and 21. J Peptide Sci.; 7: 166-72. 